\title{
UJI TINGKAT KEMATANGAN KOMPOS TERHADAP PRODUKSI TIGA VARIETAS BAWANG MERAH (Allium ascolanicumL) PADA TANAH GAMBUT
}

\author{
SelviaSutriana $^{1^{*}}$ dan Raisa Baharuddin ${ }^{2}$ \\ ${ }^{1,2}$ Program studi Agroteknologi Fakultas Pertanian Universitas Islam Riau \\ *Email :selviasutriana@agr.uir.ac.id E-mail : alamat@email.ac.id (email address of
}

\begin{abstract}
ABSTRAK
Pengembangan budiaya bawang merah di lahan gambut terkendala oleh kesuburan yang rendah. Penggunaan pupuk kompos dengan tingkat kematangan yang tepat dapat memperbaiki sifat lahan gambut tersebut. Penelitian ini bertujuan untuk mengetahui pengaruh tingkat kematangan kompos terhadap produksi tiga varietas bawang merah pada tanah gambut. Penelitian dilaksanakan di Kebun Percobaan Fakultas Pertanian Universitas Islam Riau dimulai bulan April - Agustus 2017. Penelitian menggunakan Rancangan Acak Lengkap Faktorial. Faktor pertama yaitu tingkat kematangan kompos $0,1,3$, dan 5 minggu, faktor kedua adalah varietas bawang merah Kampar, Medan, Brebes. Parameter yang diamati yaitu analisis kompos, analisis gambut, jumlah umbi per rumpun, diameter umbi, berat umbi basah per plot dan berat umbi kering per plot. Hasil penelitian menunjukkan bahwa hasil analisis kompos pada kematangan kompos 3 minggu menghasilkan $\mathrm{C} / \mathrm{N}$ ratio terendah (18) dari pada kematangan kompos 1 dan 5 minggu. Kompos tersebut juga memberikan kandungan unsur hara tertinggi pada $\mathrm{N}$ - total, $\mathrm{P}, \mathrm{K}$, $\mathrm{Ca}$ dan $\mathrm{Mg}$. sedangkan hasil analisis gambut pada awal dan akhir penelitian menunjukkan bahwa yang terbaik untuk $\mathrm{pH}$ adalah setelah diberi pupuk tingkat kematangan 1 minggu, untuk C-organik, N-total, P-total, K-total serta KTK pada gambut yang diberi kompos tingkat kematangan 3 minggu. Tingkat kematangan kompos 1 minggu sudah mampu meningkatkan jumlah umbi per rumpun pada varietas Kampar yaitu 7,56 umbi, berat umbi basah dan berat umbi kering per plot pada varietas Brebes yaitu 1062,83 g dan 920,83 g.
\end{abstract}

Kata kunci : bawang merah, gambu, kompos, tingkat kematangan, varietas

\begin{abstract}
Low fertility was the problem of shallot development in peat. Compost with the right level of maturity can improve the characteristic of peat. The objective of this experiment was to determining which maturity level of compost on shallot production in peat soil. It was conducted at Experimental Farm, Islamic University of Riau on April - August 2017. The research used a completely randomized design with 3 replications. Treatments were no compost, maturity level 1 week, 3 weeks, and 5 weeks and Kampar, Medan, and Brebes varieties. Compost of 3 week gave the best result on compost and peat soil analysis. However, Compost of 1 week provides the highest increase on $\mathrm{pH}$. Compost of 1 week significantly increase the number of bulb on Kampar variety ie 7.56 bulbs, while wet weight bulb and dry weight bulb per plot on Brebes variety ie $1062.83 \mathrm{~g}$ and $920.83 \mathrm{~g}$.
\end{abstract}

Keywords: shallo, compost, maturity level, peat, varieties

Diterima: 23 Februari 2019, disetujui 12 April 2019 


\section{PENDAHULUAN}

Komoditas bawang merah menjadi sayuran unggulan yang dibudidayakan petani secara intensif. Bawang merah banyak dibutuhkan sebagai bumbu pada berbagai masakan karena menghasilkan aroma dan rasa yang sedap (Kumar, Bhowmik, Chiranjib, Biswajit, \& Tiwari, 2010). Bawang merah mengandung senyawa allin dan allisin, sebagai sumber antioksidan, dan kegunaan lain yaitu sebagai obat herbal yang dapat mencegah demam, menekan kadar gula darah, kadar lemak darah, dan menekan munculnya flak pada pembuluh darah yang menyebabkan mengerasnya pembuluh darah. Kandungan gizi dari bawang merah dalam $100 \mathrm{~g}$ antara lain: air $88 \mathrm{~g}$; energi $46 \mathrm{kkal}$, lemak $0,3 \mathrm{~g}$, protein $1,5 \mathrm{~g}$, karbohidrat 9,2 g, Ca $36 \mathrm{mg}$; Fe 0,8 mg, P $40 \mathrm{mg}$, tiamin $0,03 \mathrm{mg}$, abu $1 \mathrm{~g}$; dan vitamin C $2 \mathrm{mg}$ (Mahmud \& Zulfianto, 2009)

Petani telah menggunakan beberapa varietas unggul bawang merah, seperti Bima, Brebes, Bauji, Sumenep, Thailand, Bali Ijo, Kuning, dan Super Philip yang dilepas oleh Menteri Pertanian. Selain itu varietas lokal yang sudah banyak dibudidayakan antara lain: Medan dan Kampar. Setiap varietas memiliki keunggulan masing-masing seperti ukuran, bentuk, warna, aroma umbi, kekenyalan, umur tanam, ketahanan terhadap penyakit danhujan.

Data Badan Pusat Statistik (2017) menyatakan bahwa pada tahun 2015 dan 2016 terjadi fluktuasi luas panen, sehingga mempengaruhi produksi dan produktivitasnya. Luas panen Nasional meningkat 22,53\%, untuk Provinsi Riau luas panen meningkat $82,93 \%$, tahun 2015 seluas 41 ha dan tahun 2016 menjadi 75 ha, produksi Nasional meningkat $17,71 \%$, produksi provinsi Riau meningkat $116,35 \%$, tahun 2015 produksi 140 ton dan tahun 2016 produksi meningkat 303 ton, produktivitas Nasional mengalami penurunan $3,89 \%$, produktivitas provinsi Riau meningkat 18,26\%, tahun 2015 produktivitas 3,42 ton/ha dan tahun 2016 produktivitas meningkat $4,04 \%$.

Provinsi Riau memiliki luas lahan gambut yaitu \pm 3.87 juta ha, namun hanya sekitar 19\% lahan gambut yang layak untuk pertanian (Badan Penelitian dan Pengembangan Pertanian, 2014). Seperti yang diketahui, pengembangan tanaman perkebunan (kelapa sawit) dan tanaman pangan pada lahan gambut di Provinsi Riau sudah banyak dikembangkan, sedangkan pengembangan tanaman hortikultura pada lahan gambut masih belum dimanfaatkan sebaik mungkin.

Permasalahan yang terjadi pada tanah gambut adalah kelebihan air hal ini berdampak pada kurangnya oksigen $\left(\mathrm{O}_{2}\right)$ sehingga menghambat pertumbuhan akar, selain itu kelebihan bahan organik sama dengan kapasitas sangat tinggi dan membutuhkan kapur yang banyak, kekurangan tanah mineral sama dengan daya pegang akar rendah sehingga tanaman mudah rebah sehingga menyebabkan miskin hara dan pertumbuhan tanaman menjadi kerdil (Ritung et al. 2012).

Pertumbuhan bibit ditentukan oleh media tanam yang digunakan sehingga menghasilkan pertumbuhan bibit yang optimum. Berdasarkan permasalahan yang terjadi pada tanah gambut, untuk mendapatkan hasil produksi bawang merah yang tinggi di tanah gambut diperlukan kecukupan dan kesimbangan hara mineral, diantaranya adalah penggunaan pupuk organik.

Kompos merupakan salah satu pupuk organik dari proses dekomposisi bahan-bahan organik. Dalam prosesnya pengomposan perlu diatur dan dikontrol pemberian air yang cukup, penambahan activator dan pengaturan aerasi sehingga pengomposan dapat berlangsung lebih cepat. Selama proses dekomposisi akan 
terjadi perubahan fisik dan kimia dari bahan organik sehingga menghasilkan bahan organik matang (Kutsanedzie et al. 2015). Dalam proses dekomposisi, unsur yang sangat berperan adalah adanya aktivitas mikroorganisme atau mikroba (jamur, bakteri dan aktinomycetes) (Omar et al. 2011).

Penentuan kualitas kompos ditentukan oleh tingkat kematangan kompos tersebut. Kompos yang belum matang bila digunakan dalam budidaya tanaman, maka pertumbuhan dan perkembangan tanaman akan terganggu, hal ini disebabkan karena terjadi imobilisasi atau perubahan bentuk hara $\mathrm{N}$ menjadi bentuk yang tidak tersedia bagi tanaman. Selain itu, kompos belum matang (belum stabil) yang diberikan

\section{METODE PENELITIAN}

Pelaksanaan penelitian dilakukan di lahan percobaan Fakultas Pertanian, Universitas Islam Riau, Pekanbaru. Penelitian ini berlangsung dari April Agustus 2017.

Varietas bawang merah yang digunakan adalah varietas Jawa, Bima, Brebes, Medan, dan lokal Kampar, bahan lain yang digunakan adalah pupuk kompos sisa tanaman jagung, NPK. Peralatan untuk budidaya tanaman seperti cangkul, lebel, cat, alat ukur, paku, handsprayer, alat penyiram tanaman, garu, alat dokumentasi dan alat tulis.

Penelitian ini merupakan penelitian factorial, factor pertama yaitu tingkat kematangan kompos dengan 4 taraf kematangan yaitu; control (tanpa diberi kompos); tingkat kematangan 1 minggu, tingkat kematangan 3 minggu, dn tingkat kematangan 5 minggu. Factor kedua adalah varietas bawang merah yaitu varietas Kampar, Medan, dan Bima Brebes. Setiap perlakuan diulang 3 kali. Rancangan lingkungan yang digunakan adalah Rancangan Acak Kelompok. Data pada tanah akan terdekomposisi secara anaerobik sehingga menghasilkan senyawa-senyawa fitotoksik seperti ammonia, nitrit-nitrogen, besi dan mangan. Dekomposisi di dalam tanah juga menyebabkan panas yang dapat menghambat pertumbuhan tanaman (Setyorini et al. 2006).

Potensi lahan gambut di Propinsi Riau bila dikelola dengan teknik budidaya yang tepat misalnya dengan diberikan kompos yang matang atau siap pakai diprediksi akan mampu meningkatkan hasil bawang merah di Riau. Tujuan penelitian adalah untuk mendapatkan tingkat kematangan kompos pada tiga varietas bawang merah yang ditanam pada tanah gambut.

primer yang diperoleh dianalisis dengan sidik ragam.

Kompos yang akan diuji berasal dari sisa tanaman jagung, dicacah menggunakan mesin pencacah kompos, selanjutnya untuk mempercepat proses pengomposan cacahan bahan kompos diberi aktifator EM-4 dengan dosis $1 \mathrm{~L}$ untuk tiap ton cacahan bahan kompos. EM-4 dilarutkan ke dalam air dan gula. Cacahan tanaman yang telah dicampur larutan EM-4, diaduk rata dan dibawa ke lapangan untuk dibentuk composting pile. Untuk mempertahankan kadar air 60-70\% berat kering kompos, dilakukan pemberian air. Pemberian air secukupnya dapat diketahui dengan meremas kompos jika dihasilkan beberapa tetes air perasan, menunjukkan bahwa air tersebut telah cukup. Pengadukan dan pembalikan dilakukan 2 kali seminggu.Waktu pengomposan disesuai dengan taraf perlakuan. Pemberian kompos dilakukan seminggu sebelum tanam.

Ukuran plot yang digunakan yaitu $1 \mathrm{~m} \times 1 \mathrm{~m}$. Sebelum ditanam, bibit 
bawang merah dipotong $1 / 3$ bagian ujung umbi, kemudian ditanam 1 bibit per lubang tanam dan jarak tanam yang digunakan adalah $20 \mathrm{~cm}$ x $20 \mathrm{~cm}$. Pupuk NPK diberikan pada saat tanam dengan dosis30 $\mathrm{g} \mathrm{plot}^{-1}$ atau $300 \mathrm{~kg} \mathrm{ha}^{-1}$.

Panen dilakukan terhadap umbi yang sudah memenuhi kriteria panen yang ditandai dengan menguningnya daun, dan $60-70 \%$ daun mulai rebah

\section{HASIL DAN PEMBAHASAN}

\section{Analisis Kompos}

Tabel 1 menunjukkan bahwa hasil analisis hara kompos serasah jagung yang diuji sesuai dengan standar kompos SNI 197030-2004, yaitu kandungan C-Organik (9.8-32\%), N (lebih tinggi dari $0.4 \%$ ), $\mathrm{P}_{2} \mathrm{O}_{5}$ (lebih tinggi dari $0.1 \%$ ) pada kompos 1, 3 dan 5 minggu, serta kandungan $\mathrm{K}_{2} \mathrm{O}$ (lebih besar dari $0.2 \%$ ) pada kompos 1 dan 3 minggu. Selain kandungan unsur hara, parameter yang penting untuk menentukan kualitas kompos adalah $\mathrm{C} / \mathrm{N}$ rasio. Nilai $\mathrm{C} / \mathrm{N}$ rasio
Pengamatan dilakukan terhadap kompos, tanah, dan hasil tanaman. Pengamatan pada kompos untuk mengetahui kandungan $\mathrm{N}, \mathrm{P}, \mathrm{K}, \mathrm{Ca}, \mathrm{Mg}$, dan $\mathrm{C} / \mathrm{N}$ rasio.Pengujian hara tanah dilakukan sebelum dan setelah perlakuan.Peubah hasil tanaman meliputi jumlah umbi per rumpun, diameter umbi, berat umbi basah per plot, dan berat umbi kering per plot.

kompos yang dihasilkan juga memenuhi standar Permentan yaitu berada direntang 10-25. Nilai $\mathrm{C} / \mathrm{N}$ rasio menurun dengan menigkatnya umur kompos. Hal ini berkaitan dengan proses dekomposisi, dengan meningkatnya umur kompos dimana proses dekomposisi berjalan maksmimal, dimana ketersediaan karbon dan nitrogen yang dihasilkan digunakan oleh mikroorganisme secara maksmimal serta serta membantu mikroorganisme untuk merombak senyawa organik kompos (Dewilda \&Apris, 2016).

Tabel 1. Hasil Analisis Kompos

\begin{tabular}{lccccc}
\hline \multirow{2}{*}{ Tingkat Kematangan } & \multicolumn{5}{c}{ Hara } \\
\cline { 2 - 6 } Kompos & $\mathbf{C - O r g a n i k}$ & $\mathbf{N}$ & $\mathbf{P}$ & $\mathbf{K}$ & $\mathbf{C} / \mathbf{N}$ \\
& $\mathbf{\%}$ & $\mathbf{\%}$ & $\mathbf{\%}$ & $\boldsymbol{\%}$ & \\
\hline 1 minggu & 21.33 & 0.91 & 0.93 & 0.79 & 23.42 \\
3 minggu & 24.90 & 1.33 & 3.15 & 0.57 & 18.67 \\
5 minggu & 26.54 & 1.31 & 0.57 & 0.11 & 20.32 \\
\hline
\end{tabular}

Penelitian ini menggunakan kompos yang berasal dari serasah jagung. Berdasarkan hasil analisis kompos, unsurunsur hara yang terkandung dalam kompos serasah jagung sangat dibutuhkan untuk pertumbuhan dan produksi tanaman. Kandungan C-Organik dalam pupuk organik menjadi unsur penting karena akan menambah bahan organik pada tanah. Kandungan C-organik dari kompos ini berkisar antara 21-26\% dan memenuhi syarat untuk pupuk organik. Salah satu manfaat pemberian pupuk kompos sebagai pupuk organik ke dalam tanah adalah untuk meningkatkan kandungan bahan organik kedalam tanah (Kusumawati, 2015).

Nilai $\mathrm{C} / \mathrm{N}$ rasio menentukan kualitas kompos, karena mempengaruhi tersedianya unsur hara pada kompos 
(Syafii et al. 2014). Nilai $\mathrm{C} / \mathrm{N}$ pada kompos merupakan indikasi tingkat kematangan kompos, $\mathrm{C} / \mathrm{N}$ rasio yang semakin tinggi mengindikasikan kompos belum matang (Surtinah, 2013). Hasil analisis $\mathrm{C} / \mathrm{N}$ masing-masing kompos berkisar antara 18.67-23.42 (Tabel 1). Hal ini menunjukkan bahwa kompos telah matang dan sudah memenuhi standar SNI dan Permentan, yaitu di bawah 25. Menurut Susanti (2015), kompos yang berasal dari residu pertanian umumnya memiliki $\mathrm{C} / \mathrm{N}$ rasio yang relatif mendekati $\mathrm{C} / \mathrm{N}$ rasio tanah akibatnya perubahan bahan kompos menjadi kompos lebih cepat.

Secara umum kandungan unsur hara $(\mathrm{N}, \mathrm{P}, \mathrm{K}, \mathrm{Ca}$, dan $\mathrm{Mg}$ ) tertinggi dan nilai $\mathrm{C} / \mathrm{N}$ rasio terendah dimiliki pada kompos umur 3 minggu. Hal ini dikarenakan pada kompos umur 3 minggu terjadi defisiensi nilai rasio $\mathrm{C} / \mathrm{N}$ yang besar sehingga proses pengomposan berlangsung lebih cepat dan baik. Proses pengomposan yang baik akan meningkatkan nilai unsur hara pada kompos (Putro et al., 2012).

\section{Analisis Gambut}

Hasil analisis tanah gambut sebelum penelitian mempunyai $\mathrm{pH}$ yang tergolong rendah dan masam yaitu 4.01 (Tabel 2), baik untuk $\mathrm{pH} \mathrm{H} 2 \mathrm{O}$ maupun $\mathrm{pH} \mathrm{KCl}$. Pada tanah masam umumnya dihadapi beberapa kendala yaitu unsur $\mathrm{P}$ kurang tersedia, kekurangan unsur $\mathrm{N}$ dan $\mathrm{K}$. Hal ini terlihat pada Tabel 2, dimana unsur $\mathrm{P}$, dan $\mathrm{K}$ sebelum perlakuan kompos kategori sangat rendah, namun kandungan $\mathrm{N}$ dalam kategori tinggi.

Tabel 2. Hasil analisis tanah sebelum dan setelah perlakuan

\begin{tabular}{lrrrr}
\hline Analisis & Sebelum & \multicolumn{3}{c}{ Setelah perlakuan } \\
\cline { 3 - 5 } perlakuan & 1 minggu & $\mathbf{3 ~ m i n g g u}$ & $\mathbf{5}$ minggu \\
\hline $\mathrm{pH},(\mathrm{H} 2 \mathrm{O})$ & 4.01 & 5.20 & 4.04 & 5.00 \\
$\mathrm{pH},(\mathrm{KCl})$ & 3.81 & 4.74 & 3.95 & 4.90 \\
$\mathrm{C}-$ Organik, \% & 35.41 & 4.48 & 10.39 & 3.63 \\
N-Total, \% & 0.53 & 0.39 & 0.70 & 0.40 \\
P Total, me/100 g & 1.11 & 11.28 & 15.21 & 7.64 \\
K Total, me/100 g & 1.58 & 0.36 & 1.03 & 0.38 \\
KTK, me/100 g & 38.50 & 14.87 & 28.85 & 11.82 \\
\hline
\end{tabular}

Kandungan C-organik dalam tanah kategori tinggi, yaitu di atas 5\% (Tabel 2). Tanah gambut merupakan tanah organic yang berasal dari sisa-sisa tanaman atau jasad hidup (segar atau telah membusuk) telah terurai oleh mikroorganisme. Bahan organik sisa tanaman merupakan penyusun terbesar Corganik tanah. Nilai KTK tanah yang diuji termasuk kategori tinggi, kondisi ini mencerminkan tingginya kapasitas jerapan tetapi kemampuan jerapannya lemah yang menyebabkan akan terbentuk ikatan yang mudah tercuci untuk kation
Kalium, Kalsium, Magnesium, dan Natrium

Kesuburan tanah gambut rendah disebabkan unsur hara yang terkandung pada tersebut rendah, dan pada tanah gambut banyak terkandung asam organic yang dapat meracuni tanaman, tetapi asam organic tersebut justru sebagai salah satu yang dapat digunakan untuk mempertahankan unsur hara, dan sifat kimia dari tanah gambut ditentukan oleh karakteristik asam organic tersebut (Hartatik et al. 2011).

Tabel 2 juga menunjukkan hasil analisis tanah gambut sesudah diberikan 
perlakuan kompos menujukkan bahwa terjadi peningkatan $\mathrm{pH}$ tanah walaupun hanya sedikit.

Senyawa organic sederhana yang terkandung dalam kompos seperti karboksil dan fenolik memiliki kemampuan mengikat Aluminium, dan Ferum, sehingga dapat mengikat $\mathrm{H}^{+}$yang berakibat keasaman tanah akan berkurang (Maryati et al. 2014). Menurut (Bancin et al. 2016) menyatakan bahwa $\mathrm{pH}$ yang tinggi dapat mempengaruhi penyerapan unsur hara yang dibutuhkan tanaman akibatnya akan mempengaruhi pertumbuhan dan hasil bawang merah.

Kandungan C-organik tanah gambut mengalami penurunan sekitar 2569\% setelah pemberian kompos.Penurunan tertinggi terjadi pada kematangan kompos 5 minggu.Hal ini diduga terjadi karena adanya peningkatan aktifitas dekomposisi oleh mikroorganisme tanah akibat pemberian kompos.Nilai $\mathrm{C} / \mathrm{N}$ rasio tanah gambut setelah perlakuan kompos berkisar 9-14 $\%$. Kondisi ini mencerminkan bahan organic sudah terurai dengan baik (Aryanti, Yulita, Rani, \& Annisava, 2016).

Pemberian kompos dengan kematangan 1 dan 5 minggu menurunkan kandungan $\mathrm{N}$-total sebesar 0.13 dan $0.14 \%$, namun kematangan kompos 3 minggu memberikan peningkatan kandungan $\mathrm{N}$ sebesar $0.17 \%$. Kandungan $\mathrm{N}$-total setelah perlakuan masih dalam kategori sedang-tinggi. Kandungan $\mathrm{N}$ pada proses pengomposan semakin sempurna proses pengomposan maka $\mathrm{N}$ akan banyak terbentuk (Masganti, Subiksa, Nurhayati, \& Syafitri, 2014). Selain itu, $\mathrm{pH}$ yang tinggi akan mempercepat proses pengomposan yang berakibat unsur esensil akan terbentuk salah satu dominasi unsur yang dihasilkan adalah Nitrogen (Aryanti et al., 2016).

Kandungan P-total mengalami kenaikan sangat tinggi yaitu mencapai
6.5-14.1 me/100g setelah pemberian kompos. Tingkat kematangan kompos umur 3 minggu memberikan nilai $P$ tertinggi. Peningkatan kandungan $\mathrm{P}$ setelah pemberian kompos terjadi karena kompos yang diberikan mengakibatkan $\mathrm{P}$ yang terikat menjadi tersedia (Surya \& Suyono, 2013).

Pemberian kompos menurunkan kandungan K-total sebesar 0.5-1.22 me/100g. Hal ini diduga karena kandungan $\mathrm{K}$ pada kompos yang diberikan, lebih banyak diserap untuk pertumbuhan dan perkembangan tanaman.

KTK tanah setelah pemberian kompos mengalami penurunan sekitar 25$69 \%$. Walaupun terjadi penurunan KTK tanah, perlakuan kematangan kompos 3 minggu memiliki nilai 28.85 masih dalam kriteria tinggi. Pada tanah gambut yang diberi bahan organic menyebabkan kapasitas tukar kation meningkat sehingga daya jerap kation juga meningkat.

\section{Produksi Bawang Merah}

Hasil pengamatan terhadap produksi umbi memperlihatkan adanya interaksi yang nyata, begitu juga untuk pengaruh utama kedua factor adalah berpengaruh nyata. Sedangkan diameter umbi tidak memberikan pengaruh nyata. Rerata hasil pengamatan produksi setelah di uji lanjut BNJ pada p 5\% dapat dilihat pada Tabel 3.

Pada Tabel 3 dapat dilihat bahwa kombinasi tingkat kematangan kompos 1 minggu pada varietas kampar memberikan hasil tertinggi jumlah umbi per rumpun yaitu 7,56 umbi. Menurut Sumarni et al. (2012) factor genetic menentukan jumlah anakan bawang merah dibandingkan dengan factor pemupukan.

Berat umbi basah dan berat umbi kering per plot memberikan hasil tertinggi pada kombinasi tingkat kemtangan kompos 1 
minggu pada varietas brebes. Sebaliknya untuk varietas Kampar dan Medan, pemberian kompos umur 5 minggu baru mampu meningkatkan bobot basah dan bobot kering umbi per plot. Hal ini mencerminkan varietas Brebes bisa beradaptasi pada tanah gambutdan tidak terlepas dari peran akar yang berfungsi untuk proses penyerapan zat-zat dari dalam tanah untuk ditransportasikan ke seluruh tubuh sehingga menghasilkan pertambahan berat. Bertambahnya berat umbi disebabkan karena adanya pemanjangan sel yang diikuti oleh pembesaran sel. Sesuai dengan penelitian Koswara (2007) yang menyatakan bahwa varietas Brebes merupakan salah satu varietas yang mempunyai adaptasi yang luas. Berdasarkan hal ini terlihat bahwa dengan pemberian kompos dengan tingkat kematangan rendah (1 minggu), tanaman bawang merah varietas Brebes sudah mampu memberikan produksi yang maksimal.

Organ penyimpan makanan pada tanaman bawang merah adalah Anakan atau umbi. Besar kecilnya umbi ditentukan oleh jumlah daun yang berbanding lurus dengan pelepah daun.

Pengaruh utama tingkat

kematangan kompos 5 minggu (K3) memberikan hasil tertinggi pada jumlah umbi per rumpun, diameter umbi, berat umbi basah dan berat umbi kering per plot yaitu 6,96 umbi, 28,22 mm, 895,19 g, 787,78 g. Hal ini dikarenakan pada kematangan kompos umur 5 minggu, kompos telah terdekomposisi sempurna sehingga saat diaplikasikan ke tanah atau tanaman tidak terjadi imobilisasi hara.

Buah yang sedang berkemabng membutuhkan unsur N, P dan K. Menurut Sanchez (1992), P merupakan unsur yang yang sangat dibutuhkan pada tanaman penghasil umbi. Selain P, Kalium juga berperan dalam pembentukan umbi bawang merah, peranan $\mathrm{K}$ pada proses metabolisme, asimilasi, dan berbagai kegiatan fisiologis pada tanaman (Salisbury \& Ross, 1995). Kandungan N, $\mathrm{P}$, dan $\mathrm{K}$, pada kompos dapat menstimulir tumbuh dan berkembangnya umbi. N, P, dan $\mathrm{K}$ yang digunakan oleh tanaman, melalui proses asimilasi dan proses fisiologis lainnya akan menghasilkan fruktan, dan senyawa ini sangat berperan dalam pembentukan (Yetti \& Elita, 2008). Tanaman Liliaceae menyimpan fruktan di dalam umbi (Salisbury \& Ross, 1995).

Secara utama varietas brebes menghasilkan diameter umbi, berat umbi basah dan berat umbi kering per plot tertinggi yaitu 30,59 mm, 957,35 g, 831,88 g. Diikuti oleh varietas Kampar yaitu 27,05 mm, 760,08 g, 672,50 g dan varietas medan menghasilkan produksi yang rendah yaitu $23,20 \mathrm{~mm}, 589,85 \mathrm{~g}$, 493,13 g. Produktivitas bawang merah tertinggi pada varietas brebes mencapai 8,32 ton/ha, Kampar 6,72 ton/ha dan medan 4,93 ton/ha. Jika dibandingkan dengan deksripsi masing-msiang varietas hasil yang diperoleh masih rendah, ini dikarenakan kondisi iklim dan tanah gambut yang digunakan.

Hasil ketiga varietas bawang merah berbeda, kondisi ini dapat diartikan bahwa masing-masing varietas memiliki kemampuan adaptasi yang berbeda pada tanah gambut. Putrasamedja (2010) malaporkan bahwa produksi bawang merah dipengaruhi oleh factor genetik dan lingkungan.

Hasil penelitian Firmansyah et al. (2014), dilaporkan bahwa varietas Sembrani yang ditanam di lahan gambut memilki daya adaptasi yang baik, hal ini dapat dilihat dari produksinya mencapai 18,7 ton hektar ${ }^{-1}$ dalam kondisi segar, dan dalam kondisi kering adalah 9,13 ton hektar ${ }^{-1}$, dengan jumlah hari hujan 47 hari, dan curah hujan sebesar 7.734,9 mm selama dua bulan, serta $\mathrm{pH}$ tanah $<4,5$.

Sinaga et al. (2013) menyatakan bahwa daya adaptasi dari suatu varietas disebabkan karena varietas memiliki satu 
jenis genotif yang memiliki kemampuan untuk mengendalikan sifat morfologi dan fisiologi untuk beradaptasi dengan lingkungan. Selanjutnya hasil penelitian Sutriana \& Herman (2014) menjelaskan Tabel 3.Komponen Hasil dan Hasil Tanaman Bawang merah terhadap uji kematangan kompos dan varietas bawang merah bahwa varietas jawa (Brebes) pada media tumbuh gambut mampu menghasilkan berat umbi per rumpun $53,60 \mathrm{~g}$ atau $857,60 \mathrm{~g}$ per plot.

\begin{tabular}{|c|c|c|c|c|}
\hline \multirow{2}{*}{$\begin{array}{c}\text { Tingkat Kematangan } \\
\text { Kompos }\end{array}$} & \multicolumn{3}{|c|}{ Varietas Bawang Merah } & \multirow[t]{2}{*}{ Rerata } \\
\hline & Kampar & Medan & Brebes & \\
\hline \multicolumn{5}{|l|}{ Jumlah umbi per rumpun } \\
\hline Tanpa Kompos & $6.45 \mathrm{abc}$ & $4.89 \mathrm{c}$ & $6.55 \mathrm{abc}$ & $5.96 \mathrm{~b}$ \\
\hline $1 \mathrm{Minggu}$ & $7.56 \mathrm{a}$ & $5.55 \mathrm{bc}$ & $6.78 \mathrm{ab}$ & $6.63 \mathrm{ab}$ \\
\hline 3 Minggu & $5.56 \mathrm{bc}$ & $7.22 \mathrm{ab}$ & $6.44 \mathrm{abc}$ & $6.41 \mathrm{ab}$ \\
\hline 5 Minggu & $6.78 \mathrm{ab}$ & $7.11 \mathrm{ab}$ & $7.00 \mathrm{ab}$ & $6.96 \mathrm{a}$ \\
\hline $\begin{array}{l}\text { Rerata (Mean) } \\
\text { KK }(C V) 9.80 \%\end{array}$ & 6.59 & 6.19 & 6.69 & \\
\hline \multicolumn{5}{|l|}{ Diameter Umbi , mm } \\
\hline Tanpa Kompos & 25.63 & 21.43 & 29.07 & $25.38 \mathrm{~b}$ \\
\hline $1 \mathrm{Minggu}$ & 26.77 & 21.60 & 30.27 & $26.21 \mathrm{~b}$ \\
\hline 3 Minggu & 27.70 & 24.83 & 31.40 & $27.98 \mathrm{a}$ \\
\hline 5 Minggu & 28.10 & 24.93 & 31.63 & $28.22 \mathrm{a}$ \\
\hline $\begin{array}{l}\text { Rerata }(\text { Mean }) \\
\mathrm{KK}(C V) 2.67 \%\end{array}$ & $27.05 \mathrm{~b}$ & $23.20 \mathrm{c}$ & $30.59 \mathrm{a}$ & \\
\hline \multicolumn{5}{|c|}{ Berat umbi basah per plot , $\mathrm{g}$} \\
\hline Tanpa Kompos & $803.08 \mathrm{c}$ & $589.25 \mathrm{f}$ & $985.58 \mathrm{ab}$ & $792.64 \mathrm{~b}$ \\
\hline 1 Minggu & 637.75 ef & $402.50 \mathrm{~g}$ & $1062.83 \mathrm{a}$ & $701.03 \mathrm{c}$ \\
\hline 3 Minggu & $651.67 \mathrm{ef}$ & $658.83 \mathrm{def}$ & $752.08 \mathrm{~cd}$ & $687.53 \mathrm{c}$ \\
\hline 5 Minggu & $947.83 \mathrm{~b}$ & 708.83 de & $1028.92 \mathrm{ab}$ & $895.19 \mathrm{a}$ \\
\hline $\begin{array}{l}\text { Rerata }(\text { Mean }) \\
\text { KK }(C V) 4.14 \%\end{array}$ & $760.08 \mathrm{~b}$ & $589.85 \mathrm{c}$ & $957.35 \mathrm{a}$ & \\
\hline \multicolumn{5}{|c|}{ Berat umbi kering per plot , $\mathrm{g}$} \\
\hline Tanpa Kompos & $692.50 \mathrm{~b}$ & $544.17 \mathrm{c}$ & $877.50 \mathrm{a}$ & $704.72 \mathrm{~b}$ \\
\hline 1 Minggu & $599.17 \mathrm{bc}$ & $284.17 \mathrm{~d}$ & $920.83 \mathrm{a}$ & $601.39 \mathrm{c}$ \\
\hline 3 Minggu & $537.50 \mathrm{c}$ & $533.33 \mathrm{c}$ & $637.50 \mathrm{bc}$ & $569.44 \mathrm{c}$ \\
\hline 5 Minggu & $860.83 \mathrm{a}$ & $610.83 \mathrm{bc}$ & $891.67 \mathrm{a}$ & $787.78 \mathrm{a}$ \\
\hline $\begin{array}{l}\text { Rerata }(\text { Mean }) \\
\mathrm{KK}(C V) 6.69 \%\end{array}$ & $672.50 \mathrm{~b}$ & $493.13 \mathrm{c}$ & $831.88 \mathrm{a}$ & \\
\hline
\end{tabular}

\section{KESIMPULAN}

Hasil analisis kompos dan gambut terbaik pada kematangan kompos umur 3 minggu memberikan $\mathrm{C} / \mathrm{N}$ ratio terendah (18) dari pada umur kompos 1 dan 5 
Hasil analisis gambut pada awal dan akhir penelitian menunjukkan bahwa yang terbaik untuk $\mathrm{pH}$ adalah setelah diberi pupuk tingkat kematangan 1 minggu, sedangkan untuk C-organik, $\mathrm{N}$ total, P-total, K-total dan KTK pada gambut yang diberi kompostingkat kematangan 3 minggu

\section{UCAPAN TERIMA KASIH}

Ucapan terima kasih diberikan kepada Direktorat Riset dan Pengabdian Masyarakat Direktorat Jenderal Penguatan Riset dan pengembangan Kementerian Rieset, Teknologi dan Pendidikan Tinggi yang telah memberikan dana pada penelitian ini pada skema Penelitian

\section{DAFTAR PUSTAKA (TNR 12)}

Aryanti, E., Yulita, Rani, A., \& Annisava. (2016). Pemberian Beberapa Amelioran Terhadap Perubahan Sifat Kimia Tanah Gambut. Jurnal Agroteknologi, 7(1), 19-26.

Badan Penelitian dan Pengembangan Pertanian. (2014). Lahan Gambut Indonesia Pembentukan, Karakteristik, dan Potensi Mendukung Ketahanan Pangan. (F. Agus, M. Anda, A. Jamil, \& Masganti, Eds.) (Revisi). Jakarta: IAARD PRESS. Retrieved from http://nasih.staff.ugm.ac.id/wpcontent/uploads/Lahan-GambutIndonesia.-Pembentukan-

Karakteristik-dan-Potensi-

Mendukung-Ketahanan-Pangan.2014.pdf

Badan Pusat Statistik. (2017). Statistik Tanaman Sayuran dan Buah-buahan Semusim 2016. Retrieved October 7, 2017 , from https://www.bps.go.id/index.php/pub likasi/index?Publikasi\%5BtahunJudu $1 \% 5 \mathrm{D}=\&$ Publikasi\%5BkataKunci\%5 $\mathrm{D}=$ sayuran \&yt $0=$ Tampilkan

Bancin, R. R., Murniati, \& Idwar. (2016).
Tingkat kematangan kompos 1 minggu sudah mampu meningkatkan jumlah umbi per rumpun pada varietas Kampar yaitu 7,56 umbi, berat umbi basah dan berat umbi kering per plot pada varietas brebes yaitu 1062,83 g dan $920,83 \mathrm{~g}$.

Dosen Pemula, Rektor Universitas Islam Riau, Ketua Lembaga Penelitian dan Pengabdian Masyarakat Universitas Islam Riau, Dekan Fakultas Pertanian dan rekan-rekan dosen yang telah membantu dalam penelitian serta penulisan artikel ini.

Pertumbuhan dan Produksi Bawang Merah (Allium ascalonicum L.) di Lahan Gambut yang Diberi Amelioran dan Pupuk Nitrogen. JOM FAPERTA, 3(1), 1-12.

Firmansyah, M., Musaddad, D., Liana, T., Mokhtar, M., \& Yufdi, M. (2014). Uji Adaptasi Bawang Merah di Lahan Gambut Pada Saat Musim Hujan di Kalimantan Tengah. $J$. Hort., 24(2), 114-123.

Hartatik, W., Subiksa, I. G. M., \& Dariah, A. (2011). Sifat Kimia dan Fisik Tanah Gambut. In N. L. Nurida, A. Mulyani, \& F. Agus (Eds.), Pengelolaan Lahan Gambut Secara Berkelanjutan (pp. 45-56). Bogor: Balai Penelitian Tanah.

Koswara, E. (2007). Teknik Pengujian Daya Hasil Beberapa Varietas Bawang Merah Di Lahan Pasang Surut Sumatera Selatan. Buletin Teknik Pertanian, 12(1), 1-3.

Kumar, K. P. S., Bhowmik, D., Chiranjib, Biswajit, \& Tiwari, P. (2010). Allium cepa: A traditional medicinal herb and its health benefits. Journal of Chemical and Pharmaceutical 
Research, 2(3), 567-574.

Kusmana, Basuki, R., \& Kurniawan, H. (2009). Uji Adaptasi Lima Varietas Bawang Merah Asal Dataran Tinggi dan Medium pada Ekosistem Dataran Rendah Brebes. J. Hort., 19(3), 281286.

Kusumawati, A. (2015). Analisa Karakteristik Pupuk Kompos. In Seminar Nasional Universitas PGRI Yogyakarta (pp. 323-329).

Kutsanedzie, F., Ofori, V., \& Diaba, K. (2015). Maturity and Safety of Compost Processed in HV and TW Composting Systems. International Journal of Science, Technology and Society, 3(4), 202-209. https://doi.org/10.11648/j.ijsts.20150 304.24

Mahmud, M. K., \& Zulfianto, N. A. (2009). Tabel komposisi pangan Indonesia (TKPI). Jakarta: Elex Media Komputindo, Kompas Gramedia.

Maryati, Nelvia, \& Anom, E. (2014). Perubahan Sifat Kimia Tanah Sawah Saat Serapan Hara Maksimum Oleh Padi (Oryza sativa L.) Setelah Aplikasi Campuran Kompos Tandan Kosong Kelapa Sawit (TKKS) dengan Abu Boiler. Jom Faperta, 1(2), 1-14.

Masganti, Subiksa, I. G. M., Nurhayati, \& Syafitri, W. (2014). Respon Tanaman Tumpangsari (Kelapa Sawit+Nenas) terhadap Ameliorasi dan Pemupukan di Lahan Gambut Terdegradasi. In Prosiding Seminar Nasional Pengelolaan Berkelanjutan Lahan Gambut Terdegradasi untuk Mitigasi Emisi GRK dan Peningkatan Nilai Ekonomi. (pp. 117-132). Badan Penelitian dan Pengembangan Pertanian. Kementerian Pertanian.

Omar, L., Ahmed, O. H., \& Majid, N. M. A. (2011). Enhancing nutrient use efficiency of maize ( Zea mays L .) from mixing urea with zeolite and peat soil water. International Journal of the Physical Sciences, 6(14), 3330-3335.

https://doi.org/10.5897/IJPS11.091

Putrasamedja, S. (2010). Perbaikan Varietas Bawang Merah (Allium ascallonicum L) Melalui Persilangan. AGRITECH, XII(1), 1-10.

Ritung, S., Wahyunto, \& Nugroho, K. (2012). Karakteristik dan Sebaran Lahan Gambut di Sumatera, Kalimantan dan Papua. In Prosiding Seminar Nasional Pengelolaan Lahan Gambut Berkelanjutan (pp. 47-62). Bogor: Balai Besar Penelitian dan Pengembangan Sumberdaya Lahan Pertanian, Badan Penelitian dan Pengembangan Pertanian, Kementerian Pertanian.

Salisbury, F. B., \& Ross, C. W. (1995). Fisiologi Tumbuhan. Bandung: ITB.

Sanchez, P. . (1992). Sifat dan Pengelolaan Tanah Tropika. Bandung: ITB Bandung.

Setyorini, D., Saraswati, R., \& Anwar, E. K. (2006). Kompos. In R. D. M. Simanungkalit, D. A. Suriadikarta, R. Saraswati, D. Setyorini, \& W. Hartatik (Eds.), PUPUK ORGANIK DAN PUPUK HAYATI (pp. 11-40). Bogor: Balai Besar Penelitian dan Pengembangan Sumberdaya Lahan Pertanian.

Sinaga, E. M., Bayu, E. S., \& Nuriadi, I. (2013). Adaptasi Beberapa Varietas Bawang Merah (Allium ascalonicum L.) di Dataran Rendah Medan. Jurnal Online Agroekoteknologi, 1(3), 404417.

Sumarni, N., Rosliani, R., \& Basuki, R. (2012). Respons Pertumbuhan, Hasil Umbi , dan Serapan Hara NPK Tanaman Bawang Merah terhadap Berbagai Dosis Pemupukan NPK pada Tanah Alluvial. J. Hort., 22(4), 366-375.

Surtinah, S. (2013). Pengujian Kandungan Unsur Hara Dalam Kompos Yang 
Berasal Dari Serasah Tanaman Jagung Manis (Zea mays saccharata). Jurnal Ilmiah Pertanian, 11(1), 11-17.

Surya, R. E., \& Suyono. (2013). Pengaruh Pengomposan Terhadap Rasio C / N Kotoran Ayam Dan Kadar Hara NPK Tersedia Serta Kapasitas Tukar Kation Tanah. UNESA Journal of Chemistry, 2(1), 137-144.

Susanti, D. S. (2015). Pemberian berbagai jenis kompos pada pertumbuhan dan hasil tanaman bawang merah (Allium ascalonicum 1) di kabupaten Enrekang. Agricola, 5(1), 61-69.
Sutriana, S., \& Herman. (2014). Uji tiga varietas dan media tumbuh terhadap pertumbuhan dan produksi bawang merah (Allium ascalonicum L). In Prosiding Seminar Nasional Agribisnis Universitas Islam Riau Pekanbaru.

Syafii, M., Murniati, \& Ariani, E. (2014). Aplikasi Kompos Serasah Jagung Degan Bahan Pengkaya Terhadap Pertumbuhan Dan Produksi Tanaman Jagung Manis (Zea mays saccharata Sturt). Jom Faperta, 1(2), 1-8.

Yetti, H., \& Elita, E. (2008). Penggunaan Pupuk Organik dan $\mathrm{KCl}$ pada Tanaman Bawang Merah (Allium ascalonicum L.). Sagu, 7(1), 13-18. 